\section{Kan med fordel tas med i kofferten}

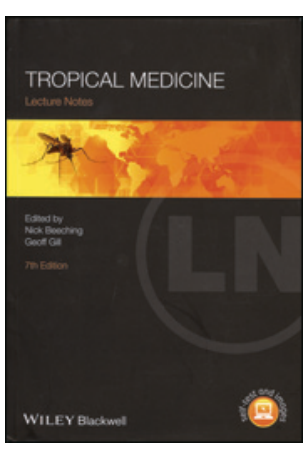

Nick Beeching, Geoff Gill, red. Tropical medicine

Lecture notes. 7. utg. 390 s, tab, ill.

Chichester: Wiley-Blackwell, 2014.

Pris GBP 26

ISBN 978-0-470-65853-6

Denne bokens intensjon er å bistå med grunnleggende kunnskap $i$ tropemedisin. Den er rettet primært mot studenter eller unge leger som forbereder seg til et opphold i tropene.

Boken har sitt opphav ved Liverpool School of Tropical Medicine, og redaktørene underviser ved skolen. Liverpool var på slutten av 1800-tallet en av de viktigste havnebyene i England. Skipene førte med seg ukjente sykdommer, og grunnleggelsen av tropemedisinskolen i 1898 var en indirekte konsekvens av dette. Innholdet representerer «pensum» for studenter som tar Diploma in Tropical Medicine and Hygiene ved London eller Liverpool School of Tropical Medicine. (Kurseksamen er for øvrig godkjent eksamen i tropemedisin og parasittologi for norske leger som spesialiserer seg i infeksjonsmedisin.) Undertegnende er i bokens målgruppe og deltok på kurset i 2012.

Den første utgaven kom i 1981, og dette er 7. utgave. Kapitlene om malaria, tuberkulose og hiv/aids er blitt oppdatert, i tillegg er det laget en nettressurs med flersvarsoppgaver og tilgang til figurene. Bokens første del beskriver differensialdiagnoser og diagnostisk tankegang med utgangspunkt i ulike symptomkomplekser, som f.eks. symptomer fra gastrointenstinalkanalen, nevrologiske symptomer og feber. I andre del gjennomgås de store tropiske sykdommene malaria, leishmaniasis, tuberkulose, hiv, onchocerciasis, trypanosomiasis, schistosomiasis og lepra relativt grundig. Siste del omtaler andre tropiske sykdommer. Eksempler er arbovirus, denguefeber, gulfeber, lus, hemoglobinopatier, bitt og stikk og underernæring. Neglisjerte tropiske sykdommer og ikke-infeksiøse sykdommer omtales i egne kapitler.

Språket er forholdsvis enkelt, og man trenger ingen forkunnskaper i tropemedisin for å forstå innholdet. Teksten er tilpasset en reell klinisk hverdag med lite materielle og menneskelige ressurser. Det er et passelig innslag av fargebilder, figurer og tabeller. Logisk inndeling og et tilstrekkelig stikkordregister gjør at det er enkelt å finne det man lurer på. På slutten av hvert kapittel er det angitt tips til videre lesing om det aktuelle emnet, og jeg opplever dette som nyttig informasjon.

Dette er selvfølgelig ingen fullstendig lærebok i tropemedisin, men etter å ha pløyd gjennom den tror jeg man sitter igjen med en ganske god oversikt. Jeg kan anbefale den som en god innføringsbok for alle leger som skal reise til tropene, eller for dem som leser til eksamen her hjemme.

\section{Gode skrivetips ved søknad om forskningsmidler}

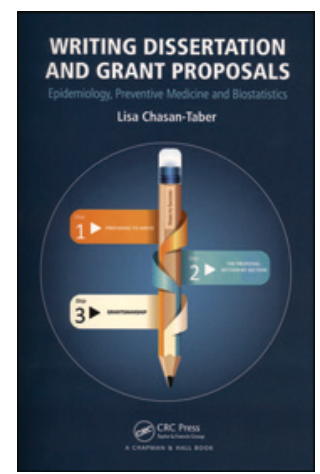

Lisa Chasan-Taber

Writing dissertation and grant proposals

Epidemiology, preventive medicine and

biostatistics

424 s, tab, ill. Boca Rato, FL: CRC Press, 2014

Pris GBP 39

ISBN 978-1-4665-1206-1

Det er stor konkurranse om forskningsmidler i Norge, og derfor stilles det høye krav til formidlingsevnen ved utarbeiding av prosjektsøknader. Forfatteren av denne utgivelsen har hatt stor suksess med egen forskningsfinansiering fra National Institutes of Health (NIH) i USA og har undervist i kunsten å skrive gode søknader om forskningsmidler.

Jeg synes boken er for kompleks for en fersk doktorgradsstudent, og en del av informasjonen er spesielt tilpasset NIH-systemet. Det er for eksempel ikke vanlig i Norge, eller EU, at man sender inn revidert søknad med svar på tidligere kritikk fra en vurderingskomité. Slike små kulturforskjeller er imidlertid ikke til hinder for at boken fremstår som meget relevant for norske forskere. Første kapittel oppsummerer nyttige poeng for å øke sjansene for å lykkes i kampen om midlene. Tipset der det anbefales å søke om midler innen et emne man «finner interessant», virker noe fremmed. Jeg mener at man virkelig bør brenne for et tema for å ha en sjanse til å nå frem i en konkurranse der bare en ørliten prosent av søkerne blir tildelt midler.

Kapitlet om å utvikle og skrive hypoteser er klargjørende. Det er gode eksempler på søknadstekster som forbedres med enkel redigering. Forskjellen mellom hypoteser og spesifikke mål, og betydningen av å presentere disse på en tydelig måte kommer godt frem. Kapitlet om litteratursøk er spesielt tilpasset forfatterens fagområder, men er relevant for alle forskningsdisipliner, og kapitlet «scientific writing» gir en utmerket innføring i emnet.

Bokens andre del er tilegnet utarbeidingen av søknaden. Praktiske og lett forståelige tips i kapitlene om styrkeberegninger og utvalgsstørrelse er relevant innen de fleste fagområder, likeledes kapitlene om bias og konfundering. Jeg likte spesielt godt tipsene $i$ kapitlet som tar for seg sammendrag og studietitler. Når man lager sammendrag, foreslår forfatteren å late som om man står på kanten av et stupebrett, og idet man hopper fra kanten, roper noen til deg: «Hva er viktig med ditt nye studieforslag?» Du roper raskt ut de viktige poengene før du treffer vannflaten. I tillegg kan man, foran en kollega, presentere muntlige svar på 4-5 sentrale spørsmål til søknaden. Verbalisering kan klargjøre svakheter, forbedre søknadssammendraget og øke sjansen for å få tildelt midler.

Jeg kjenner ikke til tilsvarende lærebøker innenfor feltet, selv om flere konsulentfirmaer gir gode tips som er spesifikt tilpasset for eksempel EUs søknadssystem. Alt i alt anbefaler jeg denne boken som en nyttig oppslagsbok og som inspirasjon for alle forskningsgrupper innen biomedisin og helse. Lykke til i neste søknadsrunde!

Annetine Staff

Overlege, Kvinne- og barneklinikken

Oslo universitetssykehus 